\title{
Eulimacrostoma gen. nov., a new genus of Eulimidae (Gastropoda, Caenogastropoda) with description of a new species and reevaluation of other western Atlantic species
}

\author{
Leonardo Santos de Souza ${ }^{1}$, Alexandre Dias Pimenta ${ }^{1}$ \\ 1 Malacologia, Departamento de Invertebrados, Museu Nacional, Universidade Federal do Rio de Janeiro, Quinta da Boa Vista, São Cristóvão, \\ 20940-040, Rio de Janeiro, RJ, Brazil \\ http://zoobank.org/954FD888-055A-4151-947A-9055B02DA514 \\ Corresponding author: Leonardo Santos de Souza (leosouza2301@gmail.com)
}

Academic editor: Matthias Glaubrecht • Received 14 February 2019 • Accepted 28 June 2019 • Published 25 July 2019

\begin{abstract}
A new genus and a new species of Eulimidae are described based on the shell morphology and on the host-parasite relationship of the type species. Eulimacrostoma microsculpturata Souza \& Pimenta gen. nov. and sp. nov. parasitizes a starfish of the genus Luidia and has an elongated, conical, straight, or slightly curved shell, a protoconch with a brownish spiral band and convex whorls, a peculiar large and broad aperture with a strongly protruding outer lip, and microsculpture of axial lines on the teleoconch. Four other species are included in the genus, all from the western Atlantic: Eulimacrostoma chascanon (Watson, 1883), comb. nov., Eulimacrostoma fusus (Dall, 1889), comb. nov., Eulimacrostoma lutescens (Simone, 2002), comb. nov., and Eulimacrostoma patula (Dall \& Simpson, 1901), comb. nov. Newly available material of Eulimacrostoma patula expands the known geographic distribution of this species in the Caribbean to the north coast of Brazil. Eulimacrostoma chascanon and Eulimacrostoma fusus and Eulimacrostoma lutescens are known only by the type series which was re-examined. A redescription is provided for Eulimacrostoma chascanon and Eulimacrostoma fusus. Species within Eulimacrostoma differ mainly by teleoconch sculpture, the presence or absence of an umbilical fissure, and shell dimensions. Lectotypes are designated for Eulimacrostoma chascanon, Eulimacrostoma fusus, and Eulimacrostoma patula.
\end{abstract}

\section{Key Words}

biodiversity, micromolluscs, parasitic snails shell morphology, taxonomy, Vanikoroidea

\section{Introduction}

Eulimidae Philippi, 1853 is a diverse group of marine gastropods comprising more than 1,000 valid species and more than 90 valid genera (MolluscaBase 2018). A massive collection effort in New Caledonia included eulimids as one of the most species-rich families of marine gastropods and about $80 \%$ of the species were possibly new to science (Bouchet et al. 2002). Eulimids are parasites of the five extant classes of Echinodermata and shows different life strategies (e.g., ectoparasitism, endoparasitism, gall formers) (Warén 1983; Takano and Kano 2014).

Warén (1983) suggested that all species in a given genus parasitize a single class of Echinodermata, with the exception of Vitreolina Monterosato, 1884, which is known to exploit ophiuroids and echinoids. Takano et al. (2018: 215) suggested that Vitreolina contains distantly related lineages and, thus, it is probably not monophyletic and Warén's (1983) rule would apply without exceptions.

Genera of Eulimidae that parasitize echinoderms of the class Asteroidea are Apicalia A. Adams, 1862, Asterolamia Warén, 1980, Asterophila Randall \& Heath, 1912, Niso Risso, 1826, Paramegadenus Humphreys \& Lützen, 1972, Parvioris Warén, 1981, Stilifer Broderip, 1832, and Thyca H. Adams \& A. Adams, 1854 (Warén 1983). The shell shape in these genera varies from the usual conical format to capuliform, or the animal is shell-less. All kinds of life strategies are present among them. 
Recently, one eulimid attached to the starfish Luidia ludwigi scotti Bell, 1917 (Luidiidae), collected in the upper bathyal zone off Florida, USA, was studied by the authors and did not correspond to any other species and genus known to parasitize asteroids or other echinoderms. The availability of a single specimen hampered the description of the taxa, but recently we identified shells of the same species from nearby localities in malacological collections, which enabled the present description.

\section{Material and methods}

The material examined is housed in the following malacological collections: Academy of Natural Sciences of Philadelphia, Drexel University, Philadelphia, Pennsylvania, USA (ANSP); Florida Museum of Natural History, Florida University, Gainesville, Florida, USA (FLMNH); Museum of Comparative Zoology, Harvard University, Cambridge, Massachusetts, USA (MCZ); Museu Nacional, Universidade Federal do Rio de Janeiro, Rio de Janeiro, Rio de Janeiro, Brazil (MNRJ); Natural History Museum, London, United Kingdom (NHMUK); Smithsonian National Museum of Natural History, Washington DC, USA (USNM).

During the course of this study, a fire destroyed several collections of MNRJ (Zamudio et al. 2018), including material cited herein. Some vouchers and types from other institutions on loan were also at the MNRJ and were destroyed. These lots are indicated with an asterisk $\left(^{*}\right)$ in the material examined.

Some samples were collected by large projects and oceanographic expeditions, such as: (1) Eolis Cruises, organized by John B. Henderson, collected by the yacht Eolis between 1910-1916 in the Florida Keys, USA (see Bieler and Mikkelsen 2002 for approximate coordinates of the collecting stations); (2) Johnson-Smithsonian Deepsea expedition, collected by the yacht Caroline in 1933, in deep waters of Puerto Rico, and sponsored by Eldridge R. Johnson (see Bartsch 1933); (3) "A Multidisciplinary Amazon Shelf Sediment Study" (AMASSEDS), collected by the Research Vessel (R/V) Columbus Iselin in 1990 near the mouth of the Amazon River, northern Brazil; (4) "Terres Australes et Antarctiques Françaises, cruise MD55" (TAAF MD55), a joint project of the "Muséum National d'Histoire Naturelle", France, and the "Universidade Santa Úrsula", Brazil, collected by the R/V Marion Dufresne between May and June 1987 (Tavares 1999).

Taxonomic identifications were based on conchological features in comparison with original descriptions and illustrations and examination of type material. Terminology of shell features follows Bouchet and Warén (1986) and Souza and Pimenta (2019). The outer lip may be opisthocline (connection at the suture behind the distal region), prosocline (connection in front of the distal region) or orthocline (in the same plane). Incremental scars are older positions of the outer lip and when present are usually deep and well demarcated; they are formed during the periodical growth of the eulimids (see Bouchet and Warén 1986: 310 for details). Microsculpture of axial lines usually appears in regular intervals, from suture to suture in each whorl and do not interrupt the suture as do the incremental scars. Growth lines are usually present at irregular intervals and do not reach from one suture to the other. Measurements of the shell are based on Souza and Pimenta (2019): shell length (SL); body whorl length (BWL); aperture length (AL); shell width (SW); aperture width (AW).

Abbreviations of generic names: Eulima Risso, 1826 (E.); Eulimacrostoma gen. nov. (Eu.).

\section{Systematics}

\section{Family Eulimidae Philippi, 1853}

Genus Eulimacrostoma Souza \& Pimenta, gen. nov. http://zoobank.org/8C4C4750-0C97-4AB1-B092-1D37ADBAE3FE

Type species. Eulimacrostoma microsculpturata Souza \& Pimenta, sp. nov. Recent, northwestern Atlantic and Caribbean.

Diagnosis. Eulimids parasitic on asteroids. Shell elongated, conical, straight or slightly curved. Protoconch subcylindrical, smooth. Teleoconch with slightly convex whorls, several incremental scars and microsculpture of axial lines, wide brownish spiral bands, a large and spread aperture, occupying between $60-70 \%$ of the body whorl length, and an orthocline outer lip, strongly protruding.

Etymology. Eulima, due to the systematic affinity and for being one of the most common names of the family, in combination with Macros, Gr. = long; and Stomatos, Gr. = mouth; in reference to the broad shape of the shell aperture.

\section{Eulimacrostoma microsculpturata Souza \& Pimenta,} sp. nov.

http://zoobank.org/F45DF003-4D73-4689-A283-20B0CD5131A6 Figures $1 \mathrm{~A}-\mathrm{G}, 2 \mathrm{~A}-\mathrm{G}$

Melanella patula auct. non. (Dall \& Simpson, 1901): Dall (1927, in part.: 67).

Type material. Holotype: USNM 429762. Paratypes: USA: Florida: Eolis stn. 307, off Fowey Light ( 25 $\left.35^{\prime} 26^{\prime \prime} \mathrm{N}, 8^{\circ} 05^{\prime} 48^{\prime \prime} \mathrm{W}, 128 \mathrm{~m}\right)$ : USNM 417624 [1 shell]; Eolis stn. 362, off Fowey Light $\left(\sim 25^{\circ} 35^{\prime} 26^{\prime \prime} \mathrm{N}\right.$, $\left.80^{\circ} 05^{\prime} 48^{\prime \prime} \mathrm{W}, 174 \mathrm{~m}\right)$ : USNM 417511* [3 shells]; Eolis stn. 370, off Ajax Reef ( $25^{\circ} 24^{\prime} 00^{\prime \prime} \mathrm{N}, 80^{\circ} 08^{\prime} 00^{\prime \prime} \mathrm{W}, 128$ 165 m): USNM 417497 [3 shells]; Eolis stn. 376, off Cae-

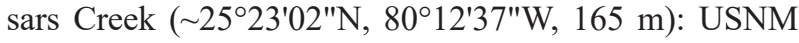
433081* [7 dd]; off Alligator Reef Light, Lower Florida Keys (183 m), coll. 21/iv/1967: ANSP 312431* [1 shell]; 


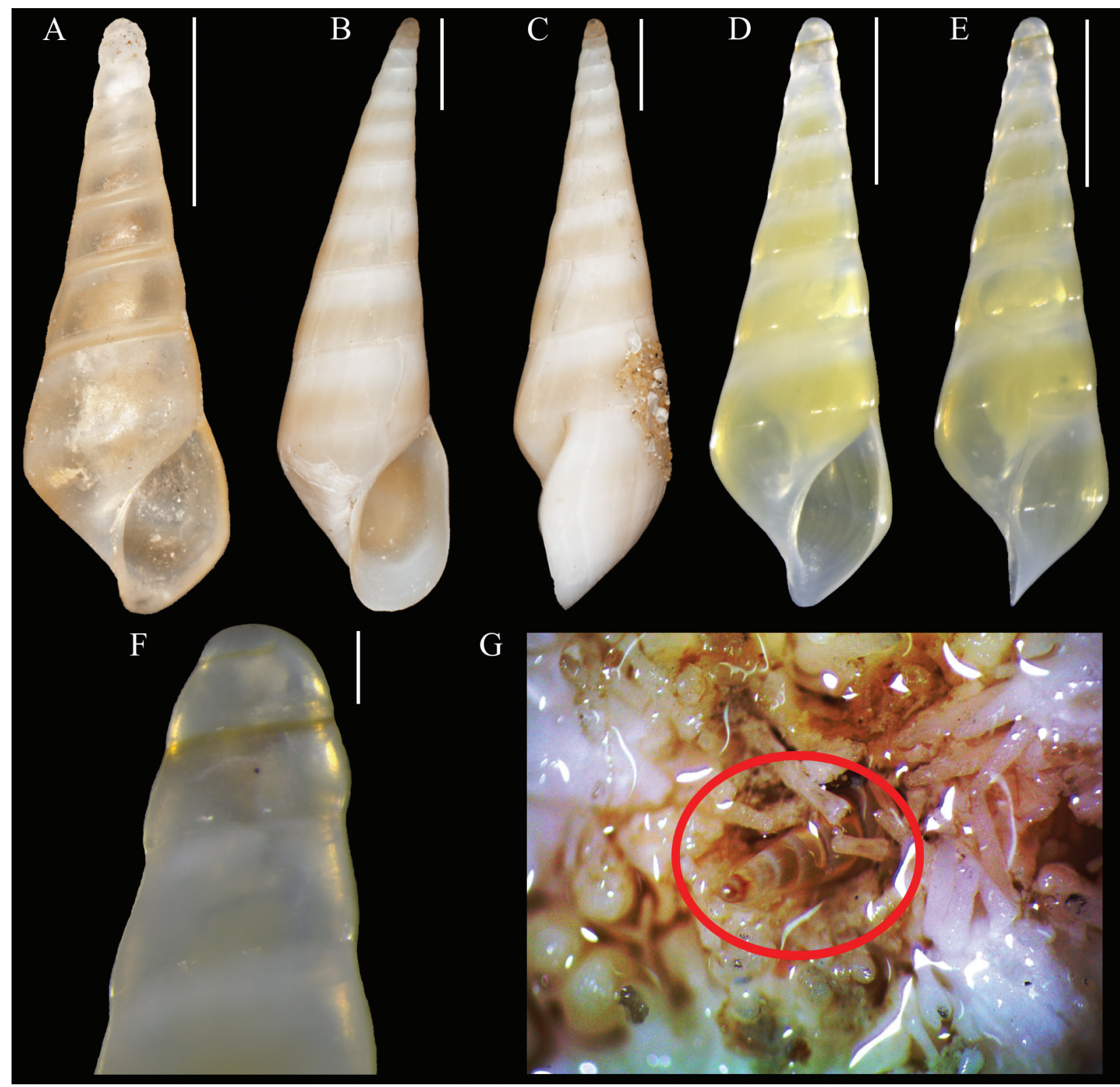

Figure 1. Eulimacrostoma microsculpturata gen. nov. and sp. nov. A. Holotype (USNM 429762); B, C. Paratype (USNM 433081); D-G. Paratype (FLMNH uncatalogued.) A, B, D. Shell in frontal view; C, E. Shell in lateral view; F. Detail of apical whorls in frontal view; G. Specimen attached to the host Luidia ludwigi scotti Bell, 1917 (Echinoderm collection, FLMNH 5042), red ellipse indicates the eulimid. Scale bars: $1 \mathrm{~mm}(\mathrm{~A}-\mathrm{E}) ; 100 \mu \mathrm{m}(\mathrm{F})$.

Eolis stn. 300, off Sand Key ( 242 $27^{\prime} 16^{\prime \prime N}, 81^{\circ} 52^{\prime} 28^{\prime \prime} \mathrm{W}$, 132 m): USNM 433039 [1 shell]; Florida Straits $\left(24^{\circ} 30^{\prime} 48.60^{\prime \prime} \mathrm{N}, 83^{\circ} 30^{\prime} 1.44^{\prime \prime} \mathrm{W}, 280 \mathrm{~m}\right)$, attached around the mouth of Luidia ludwigi scotti Bell, 1917 (FLMNH 5042, Echinodermata collection), coll. F. Michonneau, 13/iii/2007: FLMNH* (uncatalogued) [1 specimen].

Etymology. The epithet alludes to the microsculpture characteristic of the present species.

Type locality. Puerto Rico: off San Juan, Johnson-Smithsonian Deep-sea expedition stn. $10\left(18^{\circ} 29^{\prime} 20^{\prime \prime} \mathrm{N}-18^{\circ} 30^{\prime} 24^{\prime \prime} \mathrm{N}\right.$,
66 05'30"W-6604'15"W, 219-293 m), coll. Yacht Caroline, $02 / \mathrm{ii} / 1933$.

Diagnosis. Eulimid parasitic on starfish, with an elongated shell, presenting microsculpture of axial lines, domeshaped apex, a narrow brownish spiral band close to the suture in the protoconch and a wide brownish spiral band along the teleoconch, a high, wide and spread aperture. Umbilicus absent.

Description. Shell conical with an obtuse apex, reaching about $7.3 \mathrm{~mm}$ long and $2.0 \mathrm{~mm}$ wide. Protoconch vit- 


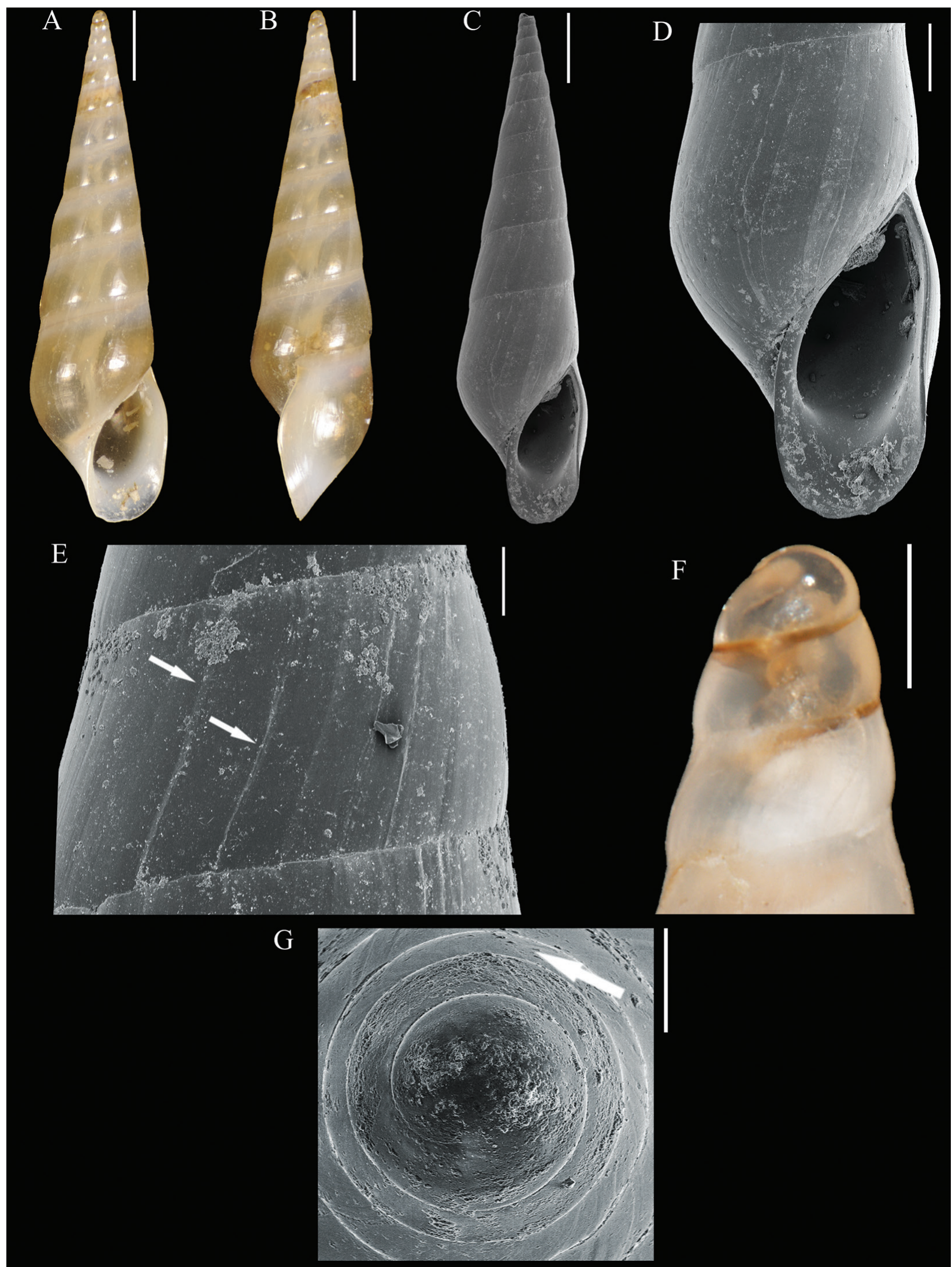

Figure 2. Eulimacrostoma microsculpturata gen. nov. and sp. nov. A-E. Paratype (ANSP 312431); F. Paratype (USNM 433081); G. Paratype (USNM 417511). A, C. whole shell in ventral view; B. Shell in lateral view; D. Detail of body whorl in frontal view; E. Detail of teleoconch surface, white arrows indicates the microsculpture of axial lines; F. Detail of apical whorls in frontal view; G. Detail of protoconch in apical view, white arrow indicates the transition protoconch-teleoconch. Scale bars: $1 \mathrm{~mm}(\mathrm{~A}-\mathrm{C})$; $500 \mu \mathrm{m} \mathrm{D}) ; 100 \mu \mathrm{m}(\mathrm{E}, \mathrm{G}) ; 200 \mu \mathrm{m}$ (F). 
Table 1. Measurements (in mm, except for number of whorls) of Eulimacrostoma species studied.

\begin{tabular}{|c|c|c|c|c|c|c|c|c|}
\hline Taxon & Catalog number & Status & Wh & SL & BWL & $\mathrm{AL}$ & SW & AW \\
\hline \multirow[t]{7}{*}{ Eu. microsculpturata } & USNM 429762 & Holotype & 8 & 3.16 & 1.60 & 1.06 & 1.08 & 0.60 \\
\hline & ANSP 312431 & Paratype & 12 & 7.28 & 3.34 & 2.21 & 1.97 & 1.17 \\
\hline & USNM 433081 & Paratype & 11 & 6.50 & 3.09 & 2.10 & 1.88 & 1.10 \\
\hline & USNM 1273894 & Paratype & 11 & 6.55 & 3.04 & 1.99 & 1.79 & 1.15 \\
\hline & USNM 1273894 & Paratype & 10.5 & 6.32 & 2.88 & 1.90 & 1.80 & 1.06 \\
\hline & USNM 433081 & Paratype & 10 & 6.03 & 2.94 & 1.97 & 1.75 & 1.03 \\
\hline & USNM 433081 & Paratype & 10 & 6.10 & 2.94 & 1.97 & 1.75 & 1.03 \\
\hline Eu. chascanon & NHMUK 1887.2.9.1587 & Lectotype & 13 & 4.49 & 1.96 & 1.23 & 1.15 & 0.65 \\
\hline \multirow[t]{2}{*}{ Eu. fusus } & USNM 87273 & Lectotype & 12 & 11.24 & 5.28 & 3.55 & 2.78 & 1.55 \\
\hline & MCZ 7515 & Paralectotype & 13 & 12.29 & 5.63 & 3.81 & 2.75 & 1.62 \\
\hline \multirow[t]{3}{*}{ Eu. lutescens } & MNHN-IM 2000-5662 & Holotype & 10 & 8.88 & 4.47 & 3.05 & 2.90 & 1.60 \\
\hline & MZSP 34514 & Paratype & $10+$ & 10.62 & 5.00 & 3.22 & 3.15 & 1.82 \\
\hline & MNHN-IM & & 9 & 7.58 & 3.75 & 2.69 & 2.28 & 1.41 \\
\hline \multirow[t]{3}{*}{ Eu. patula } & USNM 160202 & Lectotype & 9 & 4.53 & 2.20 & 1.50 & 1.50 & 0.91 \\
\hline & MNRJ 34479 & & 8.5 & 3.99 & 2.07 & 1.42 & 1.50 & 0.89 \\
\hline & MNRJ 34476 & & 9 & 4.24 & 2.07 & 1.37 & 1.42 & 0.83 \\
\hline
\end{tabular}

$\dagger$ Apex broken. Abbreviations: AL: aperture length; AW: aperture width; BWL: body whorl length; SL: shell length; SW: shell width.; Wh: whorls

reous, with a brownish spiral band close to the suture, subcylindrical, about 2.5 whorls, $300 \mu \mathrm{m}$ wide, $400 \mu \mathrm{m}$ in height, smooth, transition to teleoconch marked by a subtle incremental scar and the end of the brownish spiral band. Teleoconch with about nine whorls of sinuous outline, convexity more attenuated on the lower region of each whorl; suture deep, well impressed, sloping; subsutural zone occupying about $1 / 5$ of the whorl height; surface glossy, presenting several incremental scars and microsculpture of opisthocline axial lines; incremental scars well developed, appearing in irregular intervals; microsculpture of axial lines present at fairly regular intervals between $80-110 \mu \mathrm{m}$. Last whorl occupying about $45 \%$ of the shell length; base rounded in outline, elongated. Aperture high, occupying about $70 \%$ of the body whorl length, wide, pear-shaped, expanded laterally, acute posteriorly, rounded and spread anteriorly; outer lip thin, very sinuous, orthocline, retracted near the suture, after strongly protruding, and retracted in the distal region, maximum projection at the middle of the outer lip height; inner lip sinuous, sloping and well demarcated. Umbilicus absent. Teleoconch whitish or vitreous, fresh specimens usually have the region near the suture uncoloured and the rest of the whorl yellowish to brownish.

Measurements. Holotype USNM 429762: whorls = 8; $\mathrm{SL}=3.16 \mathrm{~mm} ; \mathrm{BWL}=1.60 \mathrm{~mm} ; \mathrm{AL}=1.06 \mathrm{~mm} ; \mathrm{SW}$ $=1.08 \mathrm{~mm} ; \mathrm{AW}=0.60 \mathrm{~mm}$. Paratype USNM 433081: Whorls $=11 ; \mathrm{SL}=6.50 \mathrm{~mm}$; $\mathrm{BWL}=3.09 \mathrm{~mm} ; \mathrm{AL}=$ $2.10 \mathrm{~mm} ; \mathrm{SW}=1.88 \mathrm{~mm} ; \mathrm{AW}=1.10 \mathrm{~mm}$.

Geographic distribution. USA: Florida; Puerto Rico.

Bathymetric distribution. From $128 \mathrm{~m}$ to $293 \mathrm{~m}$.

Remarks. Dall (1927: 67) cited 20 specimens of "Melanella patula" from "off Georgia". The USNM houses two lots (USNM 108031, USNM 108380, respectively from Fernandina, Florida, USFC stn. 2668, and from Georgia, USFC stn. 2415), that can be attributed to the material stud- ied by Dall (1927) due to the labels. USNM 108031 contains a single shell with a broken protoconch and an eroded surface. Although the shell is not in perfect condition, it is possible to affirm that it is actually Eulimacrostoma microsculpturata sp. nov. by the general shape and teleoconch sculpture. USNM 108380 contains seven shells, most of them immature, which can neither be identified with certainty as Eulimacrostoma patula (Dall \& Simpson, 1901), comb. nov. nor as Eulimacrostoma microsculpturata.

Most specimens of Eu. microsculpturata have a straight spire (Figs 1A, 2A), but individuals of the lot USNM 433081 (Fig. 1B) have a slightly curved spire. The curvature is a growth phenomenon related with the position of the incremental scars and usually helps to distinguish species (Bouchet and Warén 1986: 312). However, in the case of Eu. microsculpturata the protoconch, color pattern, shape of the aperture, and dimensions are very similar in all individuals and we consider all of them belonging to the same taxon. The holotype USNM 429762 and paratype FLMNH are young individuals and shows a more rhomboid aperture and angulated body whorl, which is a common feature at this stage of growth (Bouchet and Warén 1986: 310; Souza et al. 2018: 926).

Eulimacrostoma chascanon (Watson, 1883), comb. nov. (Fig. 3A-C) differs by the colorless shell, an aperture not so gaping anteriorly and by the proportionally smaller dimensions (Table 1). The lectotype of E. chascanon (Fig. 3A, B) is not fresh and the color pattern may have disappeared over time despite the good preservation of the shell surface.

Eulimacrostoma fusus (Dall, 1889), comb. nov. (Fig. $3 \mathrm{D}-\mathrm{I})$ differs by being proportionally greater in shell size: the lectotype with about 12 whorls is $11.24 \mathrm{~mm}$ long, whereas the holotype of Eu. microsculpturata with about 11 whorls is $6.50 \mathrm{~mm}$ long. Eulimacrostoma fusus has no color pattern and the protoconch is wider than in $E u$. microsculpturata.

Eulimacrostoma lutescens (Simone, 2002), comb. nov. (Fig. 3J-N) differs by the flatter teleoconch whorls and by the relatively wider and longer shell (holotype MNHN- 
IM 2000-5662, 10 whorls, $8.88 \mathrm{~mm}$ long, $2.90 \mathrm{~mm}$ wide vs paratype USNM 433081 of Eu. microsculpturata, 11 whorls, $6.50 \mathrm{~mm}$ long).

Eulimacrostoma patula (Fig. 4A-J) has a more truncated base, like some specimens of Eu. microsculpturata (Fig. 1A-E), but differs by the presence of an umbilical fissure and by the slightly wider spire angle.

Eulimacrostoma chascanon (Watson, 1883), comb. nov. Figure $3 \mathrm{~A}-\mathrm{C}$

Eulima chascanon Watson 1883: 114-115.

E. chascanon: Watson 1886: pl. 35, fig. 4.

Type material. Lectotype (herein designated) NHMUK 1887.2.9.1587. Paralectotype: from type locality: NHMUK Norman Coll. 1979225 [1 shell].

Material examined. Type material.

Type locality. Puerto Rico: North of Culebra Island, off St. Thomas, Challenger Expedition stn. 24 (18³8'30"N, $\left.65^{\circ} 05^{\prime} 30^{\prime \prime} \mathrm{W}, 713 \mathrm{~m}\right)$.

Redescription. Shell whitish, conical with an obtuse apex, reaching about $4.5 \mathrm{~mm}$ long and $1.2 \mathrm{~mm}$ wide, about 13 whorls. Protoconch vitreous, subcylindrical. Shell with about 13 whorls of slightly sinuous outline, with convexity more attenuated on the lower region of each whorl; suture slightly impressed, sloping; subsutural zone not visible; surface glossy, showing axial lines and incremental scars; incremental scars slightly impressed, appearing in irregular intervals. Last whorl occupying about $45 \%$ of the shell length; base rounded, elongated. Aperture high, occupying about $60 \%$ of the body whorl length, wide, pear-shaped, expanded laterally, acute posteriorly, rounded and spread anteriorly; outer lip thin, very sinuous, orthocline, strongly retracted near the suture, after strongly project, and retracted in the distal region, maximum projection below the middle of the outer lip height; inner lip sinuous, sloping and well demarcated. Umbilicus absent.

Measurements. Lectotype NHMUK 1887.2.9.1587: whorls $=13 ; \mathrm{SL}=4.49 \mathrm{~mm} ; \mathrm{BWL}=1.96 \mathrm{~mm} ; \mathrm{AL}=$ $1.23 \mathrm{~mm} ; \mathrm{SW}=1.15 \mathrm{~mm} ; \mathrm{AW}=0.65 \mathrm{~mm}$.

Geographic distribution. Known only from the type locality.

Bathymetric distribution. Known only from $713 \mathrm{~m}$.

Remarks. Eulimacrostoma chascanon comb. nov. (Fig. $3 \mathrm{~A}-\mathrm{C}$ ) presents some similarities to the new genus, such as the elongated shell with moderately convex whorls and the wide aperture with an orthocline outer lip, strongly protruding. The shell surface is very polished, but some axial lines can be observed in the types. An analysis under
SEM would confirm whether these impressions are like the kind of sculpture present in Eu. microsculpturata.

The type material of Eu. chascanon formerly consisted of two syntypes (Fig. 3A-C) housed in the NHMUK collection. The shell of NHMUK 1887.2.9.1587 is the best preserved one and seems to be the shell figured by Watson (1886: pl. 35, fig. 4), which is here selected as the lectotype (Fig. 3A, B).

Eulimacrostoma fusus (Fig. 3D-I) differs mainly by the proportionally longer shell (lectotype USNM 87273,12 whorls, $11.24 \mathrm{~mm}$ long vs lectotype NHMUK 1887.2.9.1587 of Eu. chascanon, 13 whorls, $4.49 \mathrm{~mm}$ long) and wider apex.

Eulimacrostoma lutescens (Fig. 3J-N) differs by the much wider protoconch and by the wider and longer teleoconch (holotype MNHN-IM 2000-5662, 10 whorls, $8.88 \mathrm{~mm}$ long, $2.90 \mathrm{~mm}$ wide vs lectotype NHMUK 1887.2.9.1587, 13 whorls, $4.49 \mathrm{~mm}$ long, $1.15 \mathrm{~mm}$ wide).

\section{Eulimacrostoma fusus (Dall, 1889), comb. nov.}

Figure 3D-I

Eulima fusus Dall 1889: 329, pl. 19, fig. 11B.

Strombiformis fusus: Abbott 1974: 127, fig. 1392 [reproduced from original illustration].

Type material. Lectotype (herein designated) USNM 87273. Paralectotype: Cuba: off Morro Light, "Blake" stn. 100 (457-732 m), coll. R/V Blake, xii/1878: MCZ 7515.

Material examined. Type material.

Type locality. Yucatan Strait (1170 m).

Redescription. Shell whitish, conical with an obtuse apex, reaching about $12.4 \mathrm{~mm}$ long and $2.8 \mathrm{~mm}$ wide, about 12 whorls, apical whorls slightly bent, aperture broad. Protoconch whitish, subcylindrical. Shell with about 12 whorls of slightly sinuous outline, with convexity more attenuated on the lower region of each whorl; suture well impressed, sloping; subsutural zone occupying about $1 / 5$ of the whorl height; surface glossy, showing microsculpture of axial lines and incremental scars; incremental scars well impressed, appearing in irregular intervals. Last whorl occupying about $45 \%$ of the shell length; base rounded, slightly truncated. Aperture high, occupying about $65 \%$ of the body whorl length, wide, slightly acute and spread anteriorly and acute posteriorly; outer lip thin, very sinuous, orthocline, strongly retracted near the suture, after strongly protruding, and retracted in the distal region; inner lip almost straight, well demarcated. Umbilicus absent.

Measurements. Lectotype USNM 87273: whorls = 12; $\mathrm{SL}=11.24 \mathrm{~mm} ; \mathrm{BWL}=5.28 \mathrm{~mm} ; \mathrm{AL}=3.55 \mathrm{~mm}$; $\mathrm{SW}=2.78 \mathrm{~mm} ; \mathrm{AW}=1.55 \mathrm{~mm}$.

Geographic distribution. Yucatan Strait and off Cuba. 


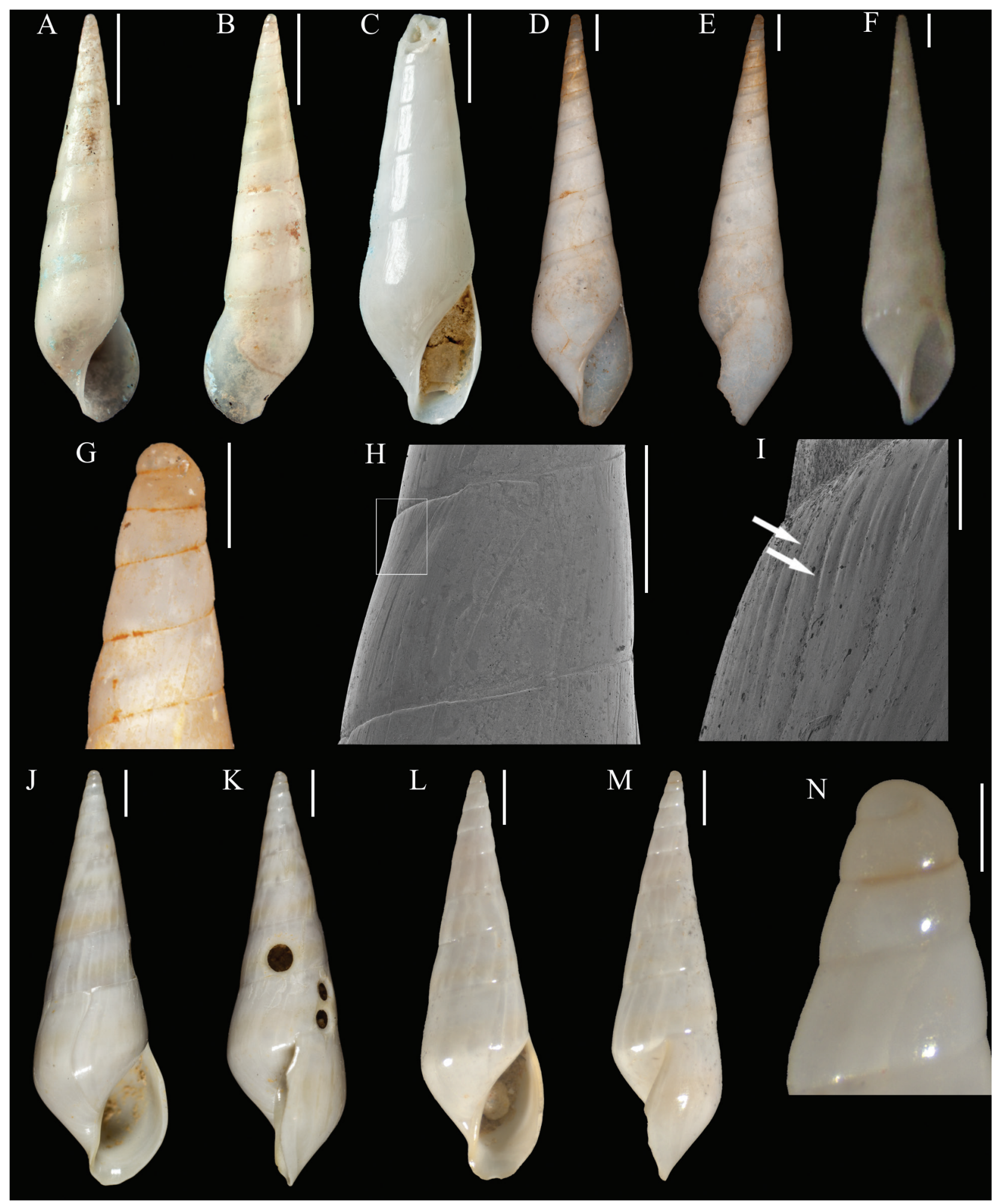

Figure 3. Eulimacrostoma spp. A-C. Eulimacrostoma chascanon (Watson, 1883), comb. nov.: A, B. Lectotype herein designated (NHMUK 1887.2.9.1587); C. Paralectotype (NHMUK Norman Coll. 1979225); D-I. Eulimacrostoma fusus (Dall, 1889), comb. nov.: D, E, G-I. Lectotype herein designated (USNM 87273); G. Paralectotype (MCZ 7515). J-N. Eulimacrostoma lutescens (Simone, 2002), comb. nov.: J, K. Holotype (MNHN-IM 2000-5662); L-N. (MNHN-IM uncatalogued), from type locality. A, C-E, G, K, M. Shell in frontal view; B. Shell in dorsal view; F, L, N. Shell in lateral view; H, O. Detail of apical whorls in frontal view; I, J. Detail of teleoconch surface, white square in I indicates detail in J, white arrows in J indicates microsculpture of axial lines. Scale bars: $1 \mathrm{~mm}(\mathrm{~A}-\mathrm{G}, \mathrm{I}, \mathrm{K}-\mathrm{N}) ; 400 \mu \mathrm{m}(\mathrm{H}) ; 50 \mu \mathrm{m}(\mathrm{J}) ; 200 \mu \mathrm{m}(\mathrm{O})$. Credits: A-C: NHMUK; H, I: USNM; J, K: MNHN-IM. 
Bathymetric distribution. From 457 to $1170 \mathrm{~m}$ (Dall 1889).

Remarks. The types of Eulimacrostoma fusus comb. nov. (Fig. 3D-I) have a partially broken aperture, resembling a channeled aperture (Dall 1889). This condition does not allow for the aperture to be perfectly described, but it is very elongated. The shell is conical, very elongated, with moderately convex and slightly distorted whorls. This species has well-demarcated axial lines in the teleoconch surface (Fig. 3H, I) and a broad subcylindrical protoconch (Figure 3G), which resembles Eu. microsculpturata.

Dall (1889) referred to two specimens from different localities, and thus these shells are originally syntypes. Here, USNM 87273 is selected as the lectotype (Fig. 3D, E, G-I).

Dall (1927: 68) recorded 18 shells off Fernandina, Florida, USA, without illustrations. The material cited by Dall was not found in the USNM and is considered dubious. There is no other additional record of the species.

Odé (1989: 67) recorded "Polygireulima fusus (Dall, 1889)" without illustrations from Texas, USA, at a depth of $110 \mathrm{~m}$. This record was based on a single specimen with $2.9 \mathrm{~mm}$ long, a very small length for the species. We could not find the voucher of Odé's record. Because there are no illustrations and the length reported by him is small in comparison to the types, we consider this a dubious record.

Eulimacrostoma lutescens (Fig. 3J-N) differs by the wider spire angle of the teleoconch in comparison to the slowly increasing diameter of the teleoconch in Eu. fusus.

Eulimacrostoma lutescens (Simone, 2002), comb. nov. Figure $3 \mathrm{~J}-\mathrm{N}$

Batheulima lutescens Simone 2002: 56, figs 5-8.

B. lutescens: Rios 2009: 194 (text figure reproduced from original illustration); Dornellas and Simone 2011: 25.

Type material. Holotype MNHN-IM 2000-5662. Paratypes: Brazil: Espírito Santo state: MD55 stn. 42 CB76 (18 58'59"S, 3749'59"W, 637 m), coll. R/V Marion Dufresne, 27/v/1987: MNHN-IM 2000-5664 [1 shell]; Rio de Janeiro state: MD55 stn. 64 CB105 (2346'59"S, 42 ${ }^{\circ} 10^{\prime} 00^{\prime \prime} \mathrm{W}, 610 \mathrm{~m}$ ), coll. R/V Marion Dufresne, 02/ vi/1987: MNHN-IM 2000-5663 [2 shells]; São Paulo state: Off São Sebastião Island $\left(23^{\circ} 47^{\prime} \mathrm{S}, 42^{\circ} 10^{\prime} \mathrm{W}\right.$, 610 m): MZSP 34514 [1 shell], MZSP 34515 [1 shell].

Material examined. Type material. Brazil: from type locality: MNHN-IM* (uncatalogued) [2 shells].

Type locality. Brazil: Espírito Santo: MD55 stn. 54 CB93 (19³6'00"S, 38 53'18"W, 640 m), coll. R/V Marion Dufresne, $30 / \mathrm{v} / 1987$.

Measurements. Holotype MNHN-IM 2000-5662: whorls $=10 ; \mathrm{SL}=8.88 \mathrm{~mm} ; \mathrm{BWL}=4.47 \mathrm{~mm} ; \mathrm{AL}=3.05$ $\mathrm{mm} ; \mathrm{SW}=2.90 \mathrm{~mm} ; \mathrm{AW}=1.60 \mathrm{~mm}$.
Geographic distribution. Brazil: Espírito Santo, Rio de Janeiro, São Paulo (Simone 2002).

\section{Bathymetric distribution. From 610 to $640 \mathrm{~m}$.}

Remarks. Simone (2002) originally included this species in Batheulima Nordsieck, 1968, but the species do not present the typical dark-brown protoconch and the sigmoidal axial lines in the protoconch like Bateulima fuscoapicata (Jeffreys, 1884), type species of the genus. Eulimacrostoma lutescens comb. nov. fits the shape of the genus erected here by the very elongated and slender shell, with an elongated, anteriorly spread aperture, and a similar color pattern. The protoconch and teleoconch of the latter species has a weak brownish spiral band (Fig. 3L, N). Additionally, the shell of Eu. lutescens has several axial lines (Simone 2002).

In addition to the type series of Eu. lutescens, we find two other shells collected from the type locality. One of them is figured here (Fig. 3L-N), and it is slightly smaller than the holotype but has one less whorl (Table 1). The initial whorls of the holotype (Fig. 3J) are straighter than in the topotype (Fig. 3L, M), but it may be variable. The topotype has a similar conical shape, with a spire angle of $21^{\circ}$ (the holotype has $23^{\circ}$ ), presence of axial lines very evident, faint brownish spiral bands in the protoconch (Fig. 3N) and teleoconch (Fig. 3L, M), a similar aperture (Fig. 3L) and a strongly protruding outer lip (Fig. 3M).

\section{Eulimacrostoma patula (Dall \& Simpson, 1901), comb. nov.}

Figure $4 \mathrm{~A}-\mathrm{K}$

Eulima (Leiostraca) patula Dall and Simpson 1901: 413, pl. 57, fig. 3.

Strombiformis patula: Abbott 1974: 127, fig. 1390 (reproduced from original illustration).

E. patula: Lamy and Pointier 2017: 277, pl. 88, fig. 3A, B.

Type material. Lectotype USNM 160202a (herein designated). Paralectotypes USNM 160202b [4 shells], from type locality.

Material examined. Type material. Brazil: Amapá state: mouth of Amazonas River, outer shelf $\left(\sim 03^{\circ} 58^{\prime} 42^{\prime \prime} \mathrm{N}\right.$, 49³3'24"W), coll. 30/vii/2001: MNRJ 34476* [4 shells], MNRJ 34477* [2 shells], MNRJ 34478* [3 shells], MNRJ $34479 *$ [8 shells]; AMASSEDS stn. $4134\left(02^{\circ} 21^{\prime} 12^{\prime \prime} \mathrm{N}\right.$, 48²9'54"W, 72 m), coll. R/V Columbus Iselin, 05/xi/1990: MNRJ 34589* [2 shells], MNRJ 35284* [1 shell].

Type locality. Puerto Rico: Mayaguez Harbour, Fish Hawk stn. 6062 (46-55 m).

Redescription. Shell vitreous or with wide brownish spiral bands, conical with an obtuse apex, reaching about $4.5 \mathrm{~mm}$ long and $1.5 \mathrm{~mm}$ wide, about eight whorls, aperture broad. Protoconch vitreous, subcylindrical, about two whorls, $330 \mu \mathrm{m}$ in width, smooth, transition to teleo- 


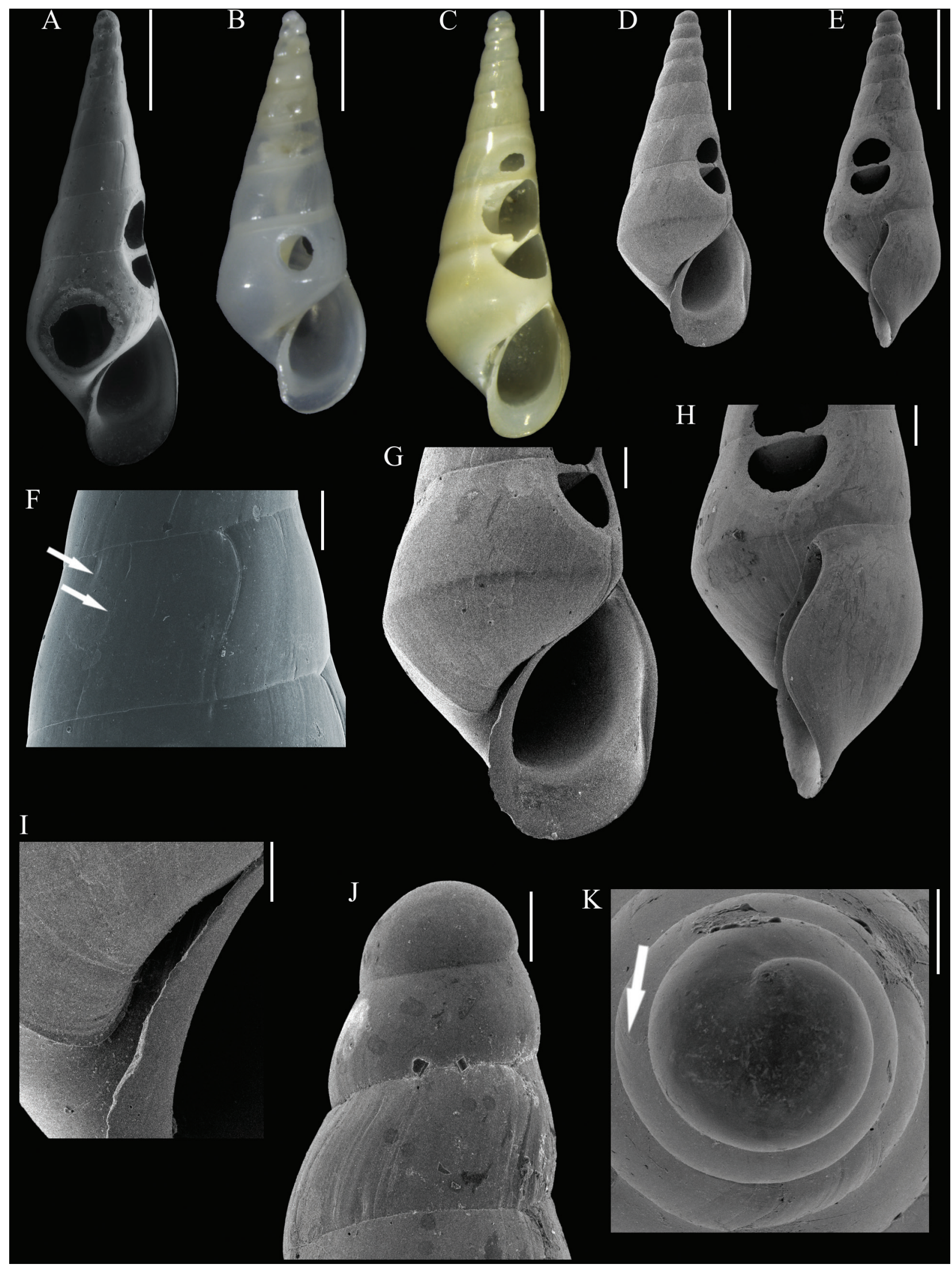

Figure 4. Eulimacrostoma patula (Dall \& Simpson, 1901), comb. nov. A. Lectotype herein designated (USNM 160202); B, F. (MNRJ 34479); C. (MNRJ 34476). D-E, G-K. (MNRJ 34589). A-D. Shell in frontal view; E. Shell in lateral view; F. Detail of teleoconch surface, white arrows indicates microsculpture of axial lines; G. Detail of body whorl in ventral view; H. detail of body whorl in lateral view; I. Detail of umbilical fissure; J. Detail of apical whorls in frontal view; K. Detail of protoconch in apical view, white arrow indicates the transition from protoconch to teleoconch. Scale bars: $1 \mathrm{~mm}(\mathrm{~A}-\mathrm{E}) ; 200 \mu \mathrm{m}(\mathrm{F}-\mathrm{H}) ; 100 \mu \mathrm{m}(\mathrm{I}-\mathrm{K})$. Credits: A: USNM. 
conch marked by a subtle incremental scar. Teleoconch with about six whorls of sinuous outline, with convexity more attenuated on the lower region of each whorl; suture deep, well impressed, sloping; subsutural zone occupying about $1 / 5$ of the whorl height; surface glossy and smooth, except for microsculpture of axial lines and incremental scars; incremental scars well developed, appearing in intervals of about 0.5 whorl. Last whorl occupying about $50 \%$ of the shell length; base slightly abrupt in outline. Aperture high, occupying about $70 \%$ of the body whorl length, wide, pear-shaped, expanded laterally, acute posteriorly, rounded and spread anteriorly; outer lip thin, very sinuous, orthocline, strongly retracted near the suture, after strongly protruding, and retracted in the distal region, maximum projection at the middle of the outer lip height; inner lip sinuous, sloping and well demarcated. Umbilical fissure present. Shell whitish or vitreous, usually with a wide brownish spiral band along the teleoconch.

Measurements. Lectotype USNM 160202: whorls = 9; $\mathrm{SL}=4.53 \mathrm{~mm} ; \mathrm{BWL}=2.20 \mathrm{~mm} ; \mathrm{AL}=1.50 \mathrm{~mm}$; $\mathrm{SW}=1.50 \mathrm{~mm} ; \mathrm{AW}=0.91 \mathrm{~mm}$.

Geographic distribution. Puerto Rico (Dall and Simpson 1901); Guadeloupe (Lamy and Pointier 2017); Brazil: Amapá (this study).

Bathymetric distribution. From $46 \mathrm{~m}$ (Dall and Simpson 1901) to $300 \mathrm{~m}$ (Lamy and Pointier 2017).

Remarks. Eulimacrostoma patula comb. nov. (Fig. 4A$\mathrm{K})$ has a combination of shell features that fit the morphology of the newly described genus, such as the elongated aperture spread anteriorly, a orthocline outer lip strongly protruding (Fig. 4G, H) and moderately convex teleoconch whorls (Fig. 4A-E). Additionally, this species usually has a weak brownish spiral band in the teleoconch (Fig. 4C).

Dall and Simpson (1901) referred to five specimens in the original description without the selection of a holotype and, thus, all shells are syntypes. We select the shell of USNM 160202 (Fig. 4A) as the lectotype.

The material from the north coast of Brazil fits perfectly with the lectotype of Eu. patula in shape and reaches a similar size (lectotype USNM 160202, 9 whorls, $4.53 \mathrm{~mm}$ long vs MNRJ 34479, 8 whorls, 3.99 mm long). The record of Eu. patula from the north coast of Brazil represents the southernmost record of this species and is more than 2,500 $\mathrm{km}$ from the type locality and about $1,800 \mathrm{~km}$ from the recent record from Guadeloupe (Lamy and Pointier 2017). This species is currently known only by empty shells.

As commented above, one shell recorded by Dall (1927: 67) is actually Eu. microsculpturata and the remaining shells found cannot be identified with certainty due to their poor condition. We did not find more material to reassess the record of Eu. patula by Dall (1927).
Parker and Curray (1956) recorded Eu. patula (as "Melanella patula") from calcareous banks off Texas and Louisiana, USA, in a depth of about $55 \mathrm{~m}$, in a checklist of species without illustrations. Odé (1989) recorded Eu. patula (as "Sabinella patula") from Texas also with no illustrations. The source of material of these records could not be traced in malacological collections and the presence of this species in the Gulf of Mexico is considered dubious.

Eulimacrostoma patula differ from the congeners mainly by the presence of an umbilical fissure and by the more truncated base.

\section{Discussion}

Eulimacrostoma gen. nov. is erected to group the eulimids with an elongated, conical shell, possessing a smooth protoconch, a teleoconch with slightly convex whorls and an enlongate and strongly anteriorly spread aperture. The species usually share a similar color pattern of brownish spiral bands in the protoconch and teleoconch, and microsculpture of axial lines in teleoconch. These latter features are more developed in the type species and in Eu. fusus and Eu. lutescens. The anatomy of Eu. microsculpturata is not described, as only one young specimen with soft parts was identified. However, the kind of host (a starfish) and the combination of shell features corroborate the distinction of this genus.

Among the eulimid genera that parasitize asteroids, the most similar to Eulimacrostoma is Niso Risso, 1826, due to its conical shape, presence of brownish spiral bands in several species and axial lines on the shell surface. However, Eulimacrostoma can be distinguished from Niso by the shape of the aperture, which gapes anteriorly and is more elongated in the former, whereas it is usually rhomboid in the latter. In addition, Niso usually has a well-developed umbilicus. The type species of Eulimacrostoma does not present an umbilicus, but Eu. patula has an umbilical fissure, which is a variable feature in relation to its presence or absence in some Eulimidae genera (e.g., Eulimetta Warén, 1992, Fusceulima Laseron, 1955) (Souza and Pimenta 2014, 2015).

Other similar genera, in relation to conchological features, that parasitize other classes of echinoderms or of unknown hosts are Batheulima, Eulima, and Haliella Monterosato, 1878.

Eulimacrostoma is similar to Batheulima, whose host is unknown (Bouchet and Warén 1986); they have an elongated aperture, with a strongly protruding outer lip and sigmoidal axial lines in the teleoconch. However, Eulimacrostoma can be distinguished by features of the protoconch, which is smooth, not completely colored.

Eulimacrostoma is also similar to Eulima, but the more typical forms of this species-rich genus that parasitizes ophiuroids have a narrower aperture, that is not so spread anteriorly, and the outline of teleoconch whorls of Eulima is usually flat. 

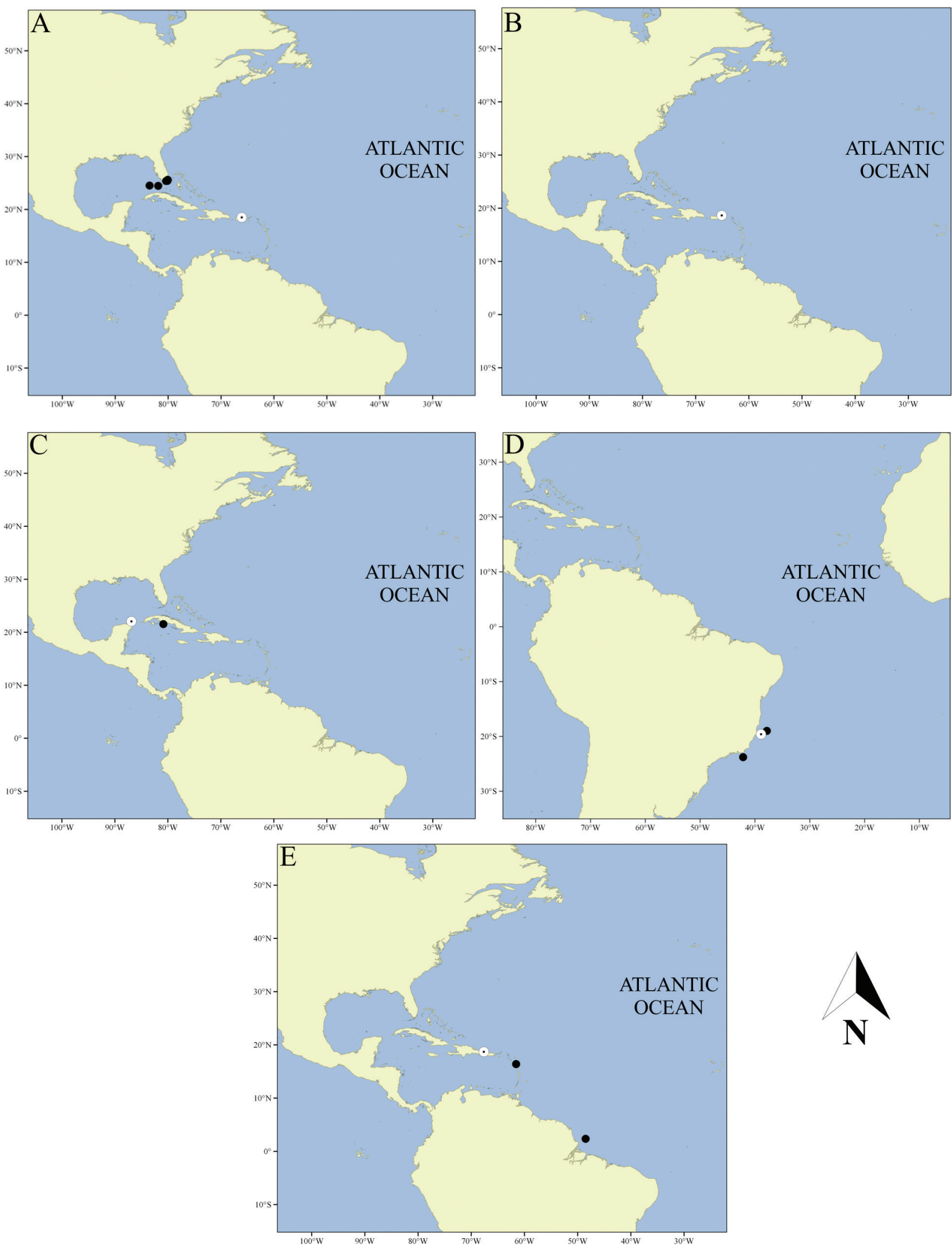

Figure 5. Geographical distributions of Eulimacrostoma spp. based on confirmed identifications. A. Eulimacrostoma microsculpturata sp. nov.; B. Eulimacrostoma chascanon (Watson, 1883), comb. nov.; C. Eulimacrostoma fusus (Dall, 1889), comb. nov.; D. Eulimacrostoma lutescens (Simone, 2002), comb. nov.; E. Eulimacrostoma patula (Dall \& Simpson, 1901), comb. nov. White circle: type locality; black circle: additional records. Records without geographic coordinates are approximate. 
Eulimacrostoma can also be compared to Haliella Monterosato, 1878 by possessing a high aperture, but the latter can be distinguished by having a more cylindrical shell, a more obtuse apex, and by being colorless. The host of Haliella species is doubtful, Warén (1983) commented that the genus possibly includes parasites of ophiuroids (Warén 1983: 47), while Hasegawa (2009: 276) noted irregular sea urchins. Hasegawa (2009) identified Haliella sp. collected in the same haul of several irregular sea urchins and ophiuroids. Despite these hypotheses, the species of Haliella have never been found on the host.

Delimitation of genera is a hard task in Eulimidae (Bouchet and Warén 1986: 310), with some exceptions. Several species and genera are known only from empty shells and/or have no data about the host and/or anatomy (e.g., Batheulima, Eulimetta, Oceanida de Folin, 1870) (Warén 1983, 1992; Bouchet and Warén 1986; Souza and Pimenta 2014, 2015).

In a revision of the family in the northeast Atlantic, Bouchet and Warén (1986) established eight new genera (including Acrochalix, Bulimeulima, Campylorhaphion, and Halielloides) known only from shell morphology and argued that they can introduce 10 more genera based exclusively on shell morphology. The introduction of these genera was justified by consistent features of the shell and the author's experience on the eulimid fauna of other regions.

The description of Eulimacrostoma is based on the combination of shell features and on data about the host of Eu. microsculpturata. Albeit only one species has the host known, all species included in Eulimacrostoma have very similar conchological features.

Recent efforts with molecular data are elucidating many aspects of the evolution of Eulimidae (Takano and Kano 2014; Takano et al. 2018), but the family is too species-rich and to reach a high percentage of DNA-sequenced taxa is a challenge. Takano et al. (2018) proposed a new methodology to identify the hosts of eulimids by extracting DNA from the proboscis of the eulimid in an attempt to find DNA traces of the host and reached successful results. This is an interesting technique, especially if the record of the eulimid attached to the host is not available.

We expect that the description of Eulimacrostoma calls the attention of researchers to congeners from other parts of the world. By now, Eulimacrostoma is known only from the western Atlantic (Fig. 5A-E). Several genera of Eulimidae have a worldwide distribution (e.g., Eulima, Fusceulima, Melanella Bowdich, 1822). The only known host of Eulimacrostoma is a starfish of the genus Luidia Forbes, 1839, which has a worldwide distribution (Mah 2019), occurring mainly in shallow waters of tropical and subtropical seas and inhabiting soft bottoms (Clark and McKnight 2000). The current state of knowledge is not sufficient to establish a specificity in the parasite-host relationship at the species or genus level. Thus, more data is necessary to reach a better comprehension about the biology of Eulimacrostoma.

\section{Acknowledgements}

We are grateful to the curators/collection managers for the loans, photographs and support during research: Gary Rosenberg, Nasreen Phillips and Paul Callomon (ANSP), Mandy Bemis and John Slapcinsky (FLMNH), Adam Baldinger (MCZ), Luiz Simone (MZSP), and Ellen Strong and Yolanda Villacampa (USNM). The first author is much indebted to his friends Carine Galvão and Gustavo Miranda for assistance during a research trip to the collections in the USA. Thanks to Nataly Slivak and Carlos Renato R. Ventura (MNRJ) for calling our attention to the eulimid attached to the starfish. Beatriz Oliveira and Camila Messias (MNRJ) for having conducted the SEM micrographs. Mauricio Fernandes (UNIRIO) who reviewed and improved an early version of this manuscript. Also, we wish to thanks Dr José H. Leal (BMSM), an anonymous reviewer, Dr Matthias Glaubrecht (Editor) and Robert Forsyth for a detailed revision of the manuscript. This work was supported by "Fundação Carlos Chagas Filho de Amparo à Pesquisa do Estado do Rio de Janeiro" (FAPERJ) under grant numbers E-26/110.325/2014 and E-26/110.068/2014. The first author is grateful to "Conselho Nacional de Desenvolvimento Científico e Tecnológico" (CNPq) and to "Coordenação de Aperfeiçoamento de Pessoal de Nível Superior" (CAPES) for a scholarship, and to Conchological Society of Great Britain and Ireland for a research grant.

\section{References}

Abbott RT (1974) American seashells. The marine Mollusca of the Atlantic and Pacific coasts of North America. Van Nostrand Reinhold Company, New York, 663 pp.

Bartsch P (1933) Station records of the first Johnson-Smithsonian deepsea expedition. Smithsonian Miscellaneous Collections 91(1): 1-31.

Bieler R, Mikkelsen PM (2002) The Cruises of the Eolis: John B. Henderson's mollusk collections off the Florida Keys, 1910-1916. American Malacological Bulletin 17(1/2): 125-140.

Bouchet P, Warén A (1986) Revision of the northeast Atlantic bathyal and abyssal Aclididae, Eulimidae, Epitoniidae (Mollusca, Gastropoda). Bollettino Malacologico Supplement 2: 299-576. https://doi. org/10.5962/bhl.title.140762

Bouchet P, Lozouet P, Maestrati P, Heros V (2002) Assessing the magnitude of species richness in tropical marine environments: exceptionally high numbers of molluscs at a New Caledonia site. Biological Journal of the Linnean Society 75: 421-436. https://doi. org/10.1046/j.1095-8312.2002.00052.x

Clark HES, McKnight DG (2000) The marine fauna of New Zealand: Echinodermata: Asteroidea (sea-stars). Order Paxillosida \& Notomyotida. NIWA Biodiversity Memoirs 116: 1-196.

Dall WH (1889) Reports on the results of dredgings, under the supervision of Alexander Agassiz, in the Gulf of Mexico (1877-78) and in the Caribbean Sea (1879-80), by the U.S. Coast Survey Steamer 'Blake'. Bulletin of the Museum of Comparative Zoology 18: 1-492. [pls 10-40] 
Dall WH, Simpson CT (1901) The Mollusca of Porto Rico. United States Fisheries Commission Bulletin 20: 351-524. [pls 53-58]

Dall WH (1927) Small shells from dredgings off the southeast coast of the United States by the United States Fisheries Steamer "Albatross" in 1885 and 1886. Proceedings of the United States National Museum 70(2667): 1-134. https://doi.org/10.5479/si.00963801.70-2667.1

Dornellas APS, Simone LRL (2011) Annotated list of type specimens of mollusks deposited in Museu de Zoologia da Universidade de São Paulo, Brazil. Arquivos de Zoologia 42(1): 1-81. https://doi. org/10.11606/issn.2176-7793.v42i1p1-81

Hasegawa K (2009) Upper bathyal gastropods of the Pacific Coast of northern Honshu, Japan, chiefly collected by R/V Wakataka-maru. In: Fujita $T$ (Ed.) Deep-sea fauna and pollutants off Pacific coast of northern Japan. National Museum of Nature and Science Monographs 39: 225-383.

Lamy D, Pointier J-P (2017) Marine and freshwater molluscs of the French Caribbean. Vol. 1-2. PLB Editions, Beta, 785 pp.

Mah CL (2019) World Asteroidea Database. Luidia Forbes, 1839. http:// www.marinespecies.org/aphia.php?p=taxdetails $\&$ id $=123260$

MolluscaBase (2018) Eulimidae Philippi, 1853. http://molluscabase. org/aphia.php? $\mathrm{p}=$ taxdetails\&id $=135$

Odé H (1989) Distribution and records of the marine Mollusca in the northwest Gulf of Mexico (a continuing monograph), superfamily Melanellacea. Texas Conchologist 25(2): 59-80.

Parker RH, Curray JR (1956) Fauna and bathymetry of banks on continental shelf, northwest Gulf of Mexico. Bulletin of the American Association of Petroleum Geologists 40: 2428-2439. https://doi. org/10.1306/5CEAE59B-16BB-11D7-8645000102C1865D

Rios EC (2009) Compendium of Brazilian sea shells. Evangraf, Rio Grande, $668 \mathrm{pp}$.

Simone LRL (2002) Three new deepwater species of Eulimidae (Caenogastropoda) from Brazil. Novapex 3(2-3): 55-60.

Souza LS, Pimenta AD (2014) Fusceulima and Halielloides (Gastropoda: Eulimidae) in the southwestern Atlantic, with descriptions of two new species of Fusceulima. Zoologia (Curitiba) 31(6): 621633. https://doi.org/10.1590/S1984-46702014000600008
Souza LS, Pimenta AD (2015) Description of a new western Atlantic species of Eulimetta (Gastropoda: Eulimidae), previously a monotypic genus from the eastern Pacific. Journal of Conchology 42(1): 57-62.

Souza LS, Pimenta AD (2019) Taxonomy of littoral Melanella (Gastropoda: Eulimidae) from Brazil, with comments on the Eulima described by Verrill and Bush (1900). Marine Biodiversity 49(1): 425-442. https://doi.org/10.1007/s12526-017-0825-x

Takano T, Kano Y (2014) Molecular phylogenetic investigations of the relationships of the echinoderm-parasite family Eulimidae within Hypsogastropoda (Mollusca). Molecular Phylogenetics and Evolution 79: 258-269. https://doi.org/10.1016/j.ympev.2014.06.021

Takano T, Itoh H, Kano Y (2018) DNA-based identification of an echinoderm host for a deep-sea parasitic snail (Gastropoda: Eulimidae) Molluscan Research 38(3): 212-217. https://doi.org/10.1080/13235 818.2017.1372865

Tavares M (1999) The cruise of the Marion Dufresne off the Brazilian coast: account of the scientific results and list of stations. Zoosystema 21(4): 597-605.

Warén A (1983) A generic revision of the family Eulimidae (Gastropoda: Prosobranchia). Journal of Molluscan Studies Supplement 13: 1-96. https://doi.org/10.1093/mollus/49.Supplement_13.1

Warén A (1992) Comments on and descriptions of eulimid gastropods from Tropical West America. The Veliger 35(3): 177-194.

Watson RB (1883) Mollusca of H.M.S. "Challenger" Expedition. Part XVII. Zoological Journal of the Linnean Society 17: 112-130. https://doi.org/10.1111/j.1096-3642.1883.tb02043.x

Watson RB (1886) Report on the Scaphopoda and Gasteropoda collected by H.M.S. Challenger during the years 1873-1876. Report on the Scientific Results of the Voyage of H.M.S. Challenger, Zoology 15(2): 1-680, 692-756. [50 pls]

Zamudio KR, Kellner A, Serejo C, Britto MR, Castro CB, Buckup PA, Pires DO, Couri M, Kury AB, Cardoso IA, Monné ML, Pombal Jr. J, Patiu CM, Padula V, Pimenta AD, Ventura CRR, Hajdu E, Zanol J, Bruna EM, Fitzpatrick J, Rocha LA (2018) Lack of Science support fails Brazil. Science 361(6409): 1322-1323. https://doi. org/10.1126/science.aav3296 